Article

\title{
Protective Effects of Evening Primrose Oil against Cyclophosphamide-Induced Biochemical, Histopathological, and Genotoxic Alterations in Mice
}

\author{
Dina M. Khodeer ${ }^{1}\left(\mathbb{D}\right.$, Eman T. Mehanna ${ }^{2}{ }^{(\mathbb{D}}$, Abdelrahman I. Abushouk ${ }^{3,4, * \mathbb{C}}$ and \\ Mohamed M. Abdel-Daim 5,6 \\ 1 Department of Pharmacology and Toxicology, Faculty of Pharmacy, Suez Canal University, Ismailia 41522, \\ Egypt; dina_khoudaer@pharm.suez.edu.eg \\ 2 Department of Biochemistry, Faculty of Pharmacy, Suez Canal University, Ismailia 41522, Egypt; \\ eman.taha@pharm.suez.edu.eg \\ 3 Faculty of Medicine, Ain Shams University, Cairo 11566, Egypt \\ 4 Department of Medicine, Harvard Medical School, Boston, MA 02215, USA \\ 5 Department of Zoology, College of Science, King Saud University, Riyadh 11451, Saudi Arabia; \\ abdeldaim.m@vet.suez.edu.eg \\ 6 Pharmacology Department, Faculty of Veterinary Medicine, Suez Canal University, Ismailia 41522, Egypt \\ * Correspondence: abdelrahman.abushouk@med.asu.edu.eg; Tel.: +20-100-514-5454
}

Received: 13 January 2020; Accepted: 3 February 2020; Published: 5 February 2020

\begin{abstract}
Cyclophosphamide (CP) is a well-known antineoplastic agent; however, its clinical use can be associated with various organ toxicities. Evening primrose oil (EPO) contains several phytoconstituents with potent anti-oxidant and anti-inflammatory activities. This experimental study was performed to investigate the chemoprotective effects of EPO in the liver and pancreas of $\mathrm{CP}$-intoxicated mice. Thirty-two albino mice were randomly divided into 4 equal groups: group I received saline (control mice), group II were treated with CP at $100 \mathrm{mg} / \mathrm{kg} /$ day for two subsequent days, and groups III and VI were treated with 5 and $10 \mathrm{mg} / \mathrm{kg} /$ day bw EPO, respectively for 14 days, followed by two doses of $\mathrm{CP}$ at the 15th and 16th days of the experiment. Then, mice were sacrificed and histopathological examinations, biochemical studies, and DNA laddering tests were conducted for hepatic and pancreatic tissues. Cyclophosphamide-intoxicated mice showed significant increases $(p<0.05)$ in the serum levels of liver enzymes, pancreatic amylase and tissue levels of malondialdehyde, and TNF- $\alpha$, as well as a significant decrease $(p<0.05)$ in the serum insulin level. In addition, both hepatic and pancreatic tissues showed disturbed tissue architecture, hydropic degeneration, congested vessels, and inflammatory infiltrates, as well as increased DNA fragmentation. In a dose-dependent manner, pretreatment with EPO was associated with significant improvements $(p<0.05)$ in all biochemical parameters and significant amelioration of histopathological alterations and DNA fragmentation in CP-intoxicated mice. Pretreatment with EPO showed significant antioxidant, anti-inflammatory, and genoprotective effects against the toxic effects of $\mathrm{CP}$ in mice hepatic and pancreatic tissues.
\end{abstract}

Keywords: cyclophosphamide; evening primrose oil; insulin; liver; pancreas; mice

\section{Introduction}

Cyclophosphamide (CP) is an alkylating chemotherapeutic drug that belongs to the class of oxazaphosporines [1,2]. It is widely used to treat various types of cancer, including lymphoma, leukemia, breast, ovarian, and lung carcinomas [3], as well as autoimmune diseases as rheumatoid arthritis (due to its immunosuppressive effects) [1]. Cyclophosphamide is metabolized via the cytochrome 
P450 system, producing acrolein and phosphoramide mustard [4]. Acrolein is a reactive aldehyde that generates toxic reactive oxygen species (ROS), leading to oxidative stress [5]. Cyclophosphamide toxicity affects many organs, including the liver and pancreas, and is characterized by depletion of glutathione, lipid peroxidation, altered DNA profile, pro-inflammatory response, and apoptosis [6,7].

Evening primrose oil (EPO) [Oenothera biennis] is a well-known alternative medication, with diverse phytoconstituents including esters, alcohols, triterpenoids, fatty acids, phenolic acids, lactones, flavonoids, tannins, sterols, and chalcone [8]. It is used traditionally as an antidiabetic drug and to treat inflammatory diseases as atopic dermatitis and rheumatoid arthritis [9]. Several studies confirmed the radical-scavenging and anti-oxidant effects of EPO $[8,10]$. Further, it was found to exert a strong lipoxygenase inhibitory effect, accounting for its anti-inflammatory activity [11]. Other research groups highlighted its hypoglycemic, hypocholesterolemic [12], anti-bacterial, and anti-fungal [13] properties. Evening primrose oil supplements, rich in linoleic and linolenic acids also improved neural function in breast cancer patients suffering from chemotherapy-induced neuropathy [14].

To our knowledge, there are no published experiments in the literature over the potential chemoprotective effects of EPO against the cytotoxicity of chemotherapeutics. Therefore, the current study was aimed to investigate the protective effects of EPO against CP-induced biochemical, histopathological, and genotoxic alterations in mice hepatic and pancreatic tissues (Figure 1).

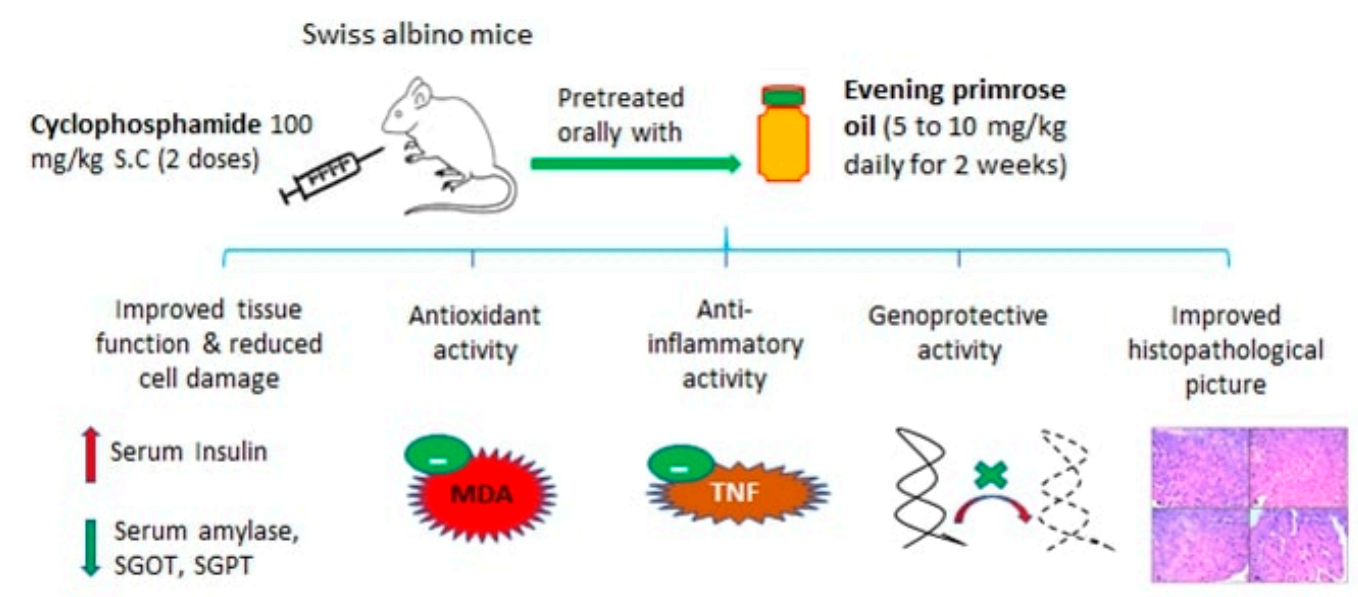

Figure 1. Summary of the experimental design and findings.

\section{Results}

\subsection{GC-MS Analysis Results}

Twenty compounds were identified in the used EPO sample. The major components in the analyzed samples were $3 \beta$-Sitosterol [stigmast-5-en-3-ol, (3ß)-; 39.8\%], campesterol [ergost-5-en-3-ol (3ß24R); 17.1\%], caryophyllene [8.2\%], and 2-(1,1-dimethylethyl)-5-(2-propenyl)-1,4-benzenediol [5.4\%]. The retention time for these compounds ranged from 8.66 to $34.02 \mathrm{~min}$. The total ion chromatogram obtained by GC-MS analysis of primrose oil is illustrated in Figure 2 and the full list of present compounds and their peak areas are shown in Table 1. 
Table 1. The chemical composition of evening primrose oil by GC-MS analysis.

\begin{tabular}{|c|c|c|c|c|c|}
\hline Peak & $\begin{array}{l}\text { Retention } \\
\text { Time }\end{array}$ & Name & Area\% & $\begin{array}{l}\text { Molecular } \\
\text { Weight }\end{array}$ & $\begin{array}{c}\text { Molecular } \\
\text { Formula }\end{array}$ \\
\hline 1 & 4.08 & Decane & 1.39 & 142 & $\mathrm{C} 10 \mathrm{H} 22$ \\
\hline 2 & 6.63 & 1-Hexadecanol, 2-methyl- & 1.13 & 256 & $\mathrm{C} 17 \mathrm{H} 36 \mathrm{O}$ \\
\hline 3 & 9.36 & Dodecane & 1.62 & 170 & $\mathrm{C} 12 \mathrm{H} 26$ \\
\hline 4 & 10.10 & $\begin{array}{l}\text { Thiophene, tetrahydro-, } \\
\text { 1,1-dioxide }\end{array}$ & 1.52 & 120 & $\mathrm{C} 4 \mathrm{H} 8 \mathrm{O} 2 \mathrm{~S}$ \\
\hline 5 & 12.10 & 2,4-Dodecadienal, (E,E)- & 0.88 & 180 & $\mathrm{C} 12 \mathrm{H} 20 \mathrm{O}$ \\
\hline 6 & 12.70 & Deca-2,4-Dienal & 1.25 & 152 & $\mathrm{C} 10 \mathrm{H} 16 \mathrm{O}$ \\
\hline 7 & 14.43 & 1-Dodecene & 0.77 & 168 & $\mathrm{C} 12 \mathrm{H} 24$ \\
\hline 8 & 14.63 & $(3 \beta, 5 \alpha)$-Cholestanol & 2.52 & 389 & $\mathrm{C} 27 \mathrm{H} 48 \mathrm{O}$ \\
\hline 9 & 17.54 & $\begin{array}{l}\text { 2-(1,1-dimethylethyl)-5-(2- } \\
\text { propenyl)-1,4-benzenediol }\end{array}$ & 5.38 & 206 & $\mathrm{C} 13 \mathrm{H} 18 \mathrm{O} 2$ \\
\hline 10 & 18.11 & Ergost-5-en-3-ol(3ß24R) & 17.10 & 401 & $\mathrm{C} 28 \mathrm{H} 48 \mathrm{O}$ \\
\hline 11 & 19.22 & 7-Hexadecene, (Z)- & 1.24 & 224 & $\mathrm{C} 16 \mathrm{H} 32$ \\
\hline 12 & 19.38 & Hexadecane & 1.63 & 226 & $\mathrm{C} 16 \mathrm{H} 34$ \\
\hline 13 & 20.30 & Caryophyllene & 8.23 & 204 & $\mathrm{C} 15 \mathrm{H} 24$ \\
\hline 14 & 21.73 & 3-Nonanol, 2-methyl- & 0.77 & 158 & $\mathrm{C} 10 \mathrm{H} 22 \mathrm{O}$ \\
\hline 15 & 23.67 & Nonadecane & 1.63 & 268 & $\mathrm{C} 19 \mathrm{H} 40$ \\
\hline 16 & 27.08 & Stigmast-5-en-3-ol, (3ß)- & 39.81 & 415 & $\mathrm{C} 29 \mathrm{H} 50 \mathrm{O}$ \\
\hline 17 & 27.44 & 1-Eicosanol & 2.05 & 298 & $\mathrm{C} 2 \mathrm{OH} 42 \mathrm{O}$ \\
\hline 18 & 27.73 & Gibberellic acid & 3.92 & 346 & $\mathrm{C} 19 \mathrm{H} 22 \mathrm{O} 6$ \\
\hline 19 & 30.20 & Linoleic acid ethyl ester & 4.51 & 308 & $\mathrm{C} 2 \mathrm{OH} 36 \mathrm{O} 2$ \\
\hline \multirow[t]{2}{*}{20} & 31.85 & $\begin{array}{c}\text { 8,11,14-Eicosatrienoic acid, } \\
(\mathrm{Z}, \mathrm{Z}, \mathrm{Z})-\end{array}$ & 2.12 & 306 & $\mathrm{C} 20 \mathrm{H} 34 \mathrm{O} 2$ \\
\hline & & & $\Sigma 99.47$ & & \\
\hline
\end{tabular}

RT: $8.66-34.02$

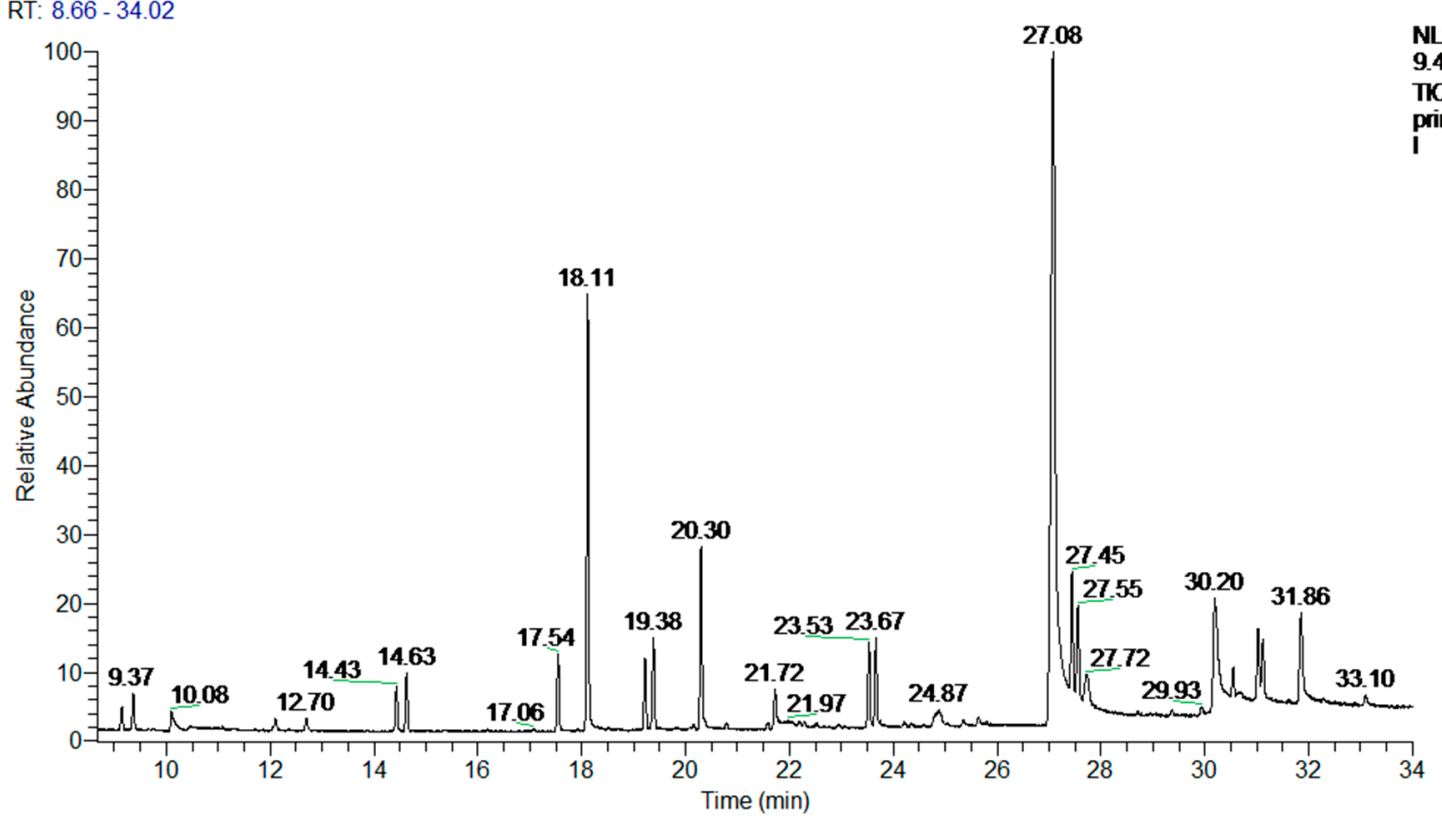

Figure 2. Total ion chromatogram obtained by GC-MS analysis of evening primrose oil. 


\subsection{Serum Biochemical Analysis}

Compared to control mice, CP-intoxicated mice had significantly higher $(p<0.05)$ serum concentrations of serum glutamic pyruvic transaminase (SGPT), serum glutamic oxaloacetic transaminase (SGOT), and pancreatic amylase, as well as significantly lower $(p<0.05)$ serum concentrations of insulin. However, mice pretreated with EPO at 5 or $10 \mathrm{mg} / \mathrm{kg} /$ day showed significant amelioration of these changes. Pretreatment with EPO at $10 \mathrm{mg} / \mathrm{kg} /$ day restored the control ranges of liver enzymes, pancreatic amylase, and insulin (Table 2).

Table 2. The protective effects of evening primrose oil against cyclophosphamide-induced changes in serum levels of liver enzymes (SGOT and SGPT), pancreatic amylase, and insulin.

\begin{tabular}{ccccc}
\hline Groups & SGPT u/L & SGOT u/L & Amylase u/L & Insulin ng/mL \\
\hline Control & $9.87 \pm 0.44$ & $35.6 \pm 3.22$ & $29.7 \pm 1.2$ & $10.43 \pm 0.3$ \\
CP-intoxicated & $24.6 \pm 1.7^{\mathrm{a}}$ & $68.6 \pm 1.7^{\mathrm{a}}$ & $55.2 \pm 1.8^{\mathrm{a}}$ & $5.5 \pm 0.26^{\mathrm{a}}$ \\
CP + EPO $(5 \mathrm{mg} / \mathrm{kg})$ & $14.6 \pm 1.26^{\mathrm{ab}}$ & $49.12 \pm 1.96^{\mathrm{ab}}$ & $44.1 \pm 1.98^{\mathrm{ab}}$ & $7.1 \pm 0.22^{\mathrm{ab}}$ \\
$\mathrm{CP}+$ EPO $(10 \mathrm{mg} / \mathrm{kg})$ & $11.87 \pm 0.6^{\mathrm{b}}$ & $41.1 \pm 0.55^{\mathrm{bc}}$ & $33.6 \pm 2.7^{\mathrm{bc}}$ & $10.7 \pm 0.69^{\mathrm{bc}}$ \\
\hline
\end{tabular}

All data are expressed as mean \pm SEM and analyzed using the one-way ANOVA, followed by Bonferroni's post-hoc test at $p<0.05$. a Significantly different from the control mice, ${ }^{\mathrm{b}}$ Significantly different from CP-intoxicated mice,

c Significantly different from CP + EPO $(5 \mathrm{mg} / \mathrm{kg})$ mice.

\subsection{Tissue Biochemical Analysis}

Significant increases $(p<0.05)$ were recorded in hepatic and pancreatic tissue concentrations of malondialdehyde (MDA) and tumor necrosis factor alpha (TNF- $\alpha$ ) following CP injections, in comparison to control mice. However, pretreatment with either dose of EPO (5 or $10 \mathrm{mg} / \mathrm{kg} / \mathrm{day}$ ) alleviated these increases. The hepatic concentrations of MDA and TNF- $\alpha$ in mice pretreated with the $10 \mathrm{mg} / \mathrm{kg} / \mathrm{day}$ dose of EPO were significantly lower $(p<0.05)$ than in those pretreated with the $5 \mathrm{mg} / \mathrm{kg} /$ day dose; Table 3.

Table 3. The effect of different doses of EPO on TNF- $\alpha$ and MDA levels in the liver and pancreas tissue homogenates of CP-intoxicated mice.

\begin{tabular}{ccccc}
\hline Groups & Liver TNF- $\alpha$ & Pancreas TNF- $\alpha$ & Liver MDA & Pancreas MDA \\
\hline Control & $53.6 \pm 5.9$ & $25.6 \pm 5.8$ & $2.2 \pm 0.21$ & $0.52 \pm 0.15$ \\
CP-intoxicated & $132.3 \pm 6.8^{\mathrm{a}}$ & $151.3 \pm 6.9^{\mathrm{a}}$ & $13.3 \pm 0.57^{\mathrm{a}}$ & $1.36 \pm 0.06^{\mathrm{a}}$ \\
$\mathrm{CP}+$ EPO $(5 \mathrm{mg} / \mathrm{kg})$ & $83.3 \pm 6.7^{\mathrm{ab}}$ & $78.3 \pm 6.6^{\mathrm{ab}}$ & $6 \pm 0.78^{\mathrm{ab}}$ & $0.59 \pm 0.08^{\mathrm{b}}$ \\
$\mathrm{CP}+$ EPO $(10 \mathrm{mg} / \mathrm{kg})$ & $56 \pm 3.8^{\mathrm{bc}}$ & $41.3 \pm 3.9^{\mathrm{ab}}$ & $3.9 \pm 0.39^{\mathrm{abc}}$ & $0.39 \pm 0.04^{\mathrm{b}}$ \\
\hline
\end{tabular}

CP: cyclophosphamide, EPO: evening primrose oil, MDA: Malondialdehyde, TNF: Tumor necrosis factor. All data were expressed as mean \pm SEM and analyzed using the one-way ANOVA followed by Bonferroni's post-hoc test at $p<0.05$. a Significantly different from control mice, ${ }^{\mathrm{b}}$ Significantly different from CP-intoxicated mice, ${ }^{\mathrm{c}}$ Significantly different from CP + EPO $(5 \mathrm{mg} / \mathrm{kg})$ mice.

\subsection{Histopathological Examination and Analysis}

Liver tissue sections from control mice showed preserved tissue architecture, formed of hepatocytes with abundant cytoplasm and small nuclei, arranged in thin cell trabeculae, and separated by thin-wall blood sinusoids with normal central vein and portal tracts (Figure 3a). In contrast, CP-intoxicated mice showed disturbed tissue architecture; hepatocytes arranged in thick and thin cell trabeculae with marked hydropic degeneration, congested dilated central veins, compressed sinusoids (due to hydropic degeneration and cell swelling of hepatocytes), and mild inflammatory infiltrates (Figure 3b). However, group III mice (CP + EPO $5 \mathrm{mg} / \mathrm{kg} /$ day) showed preserved hepatic tissue architecture; hepatocytes arranged in thin cell trabeculae with mild residual hydropic degeneration and normal sinusoids with slightly congested vessels (Figure 3c). Group IV mice (CP + EPO $10 \mathrm{mg} / \mathrm{kg} /$ day) showed marked improvements with hepatocytes arranged in thin cell trabeculae in a lobular architecture, separated by thin-wall blood sinusoids (Figure 3d). 


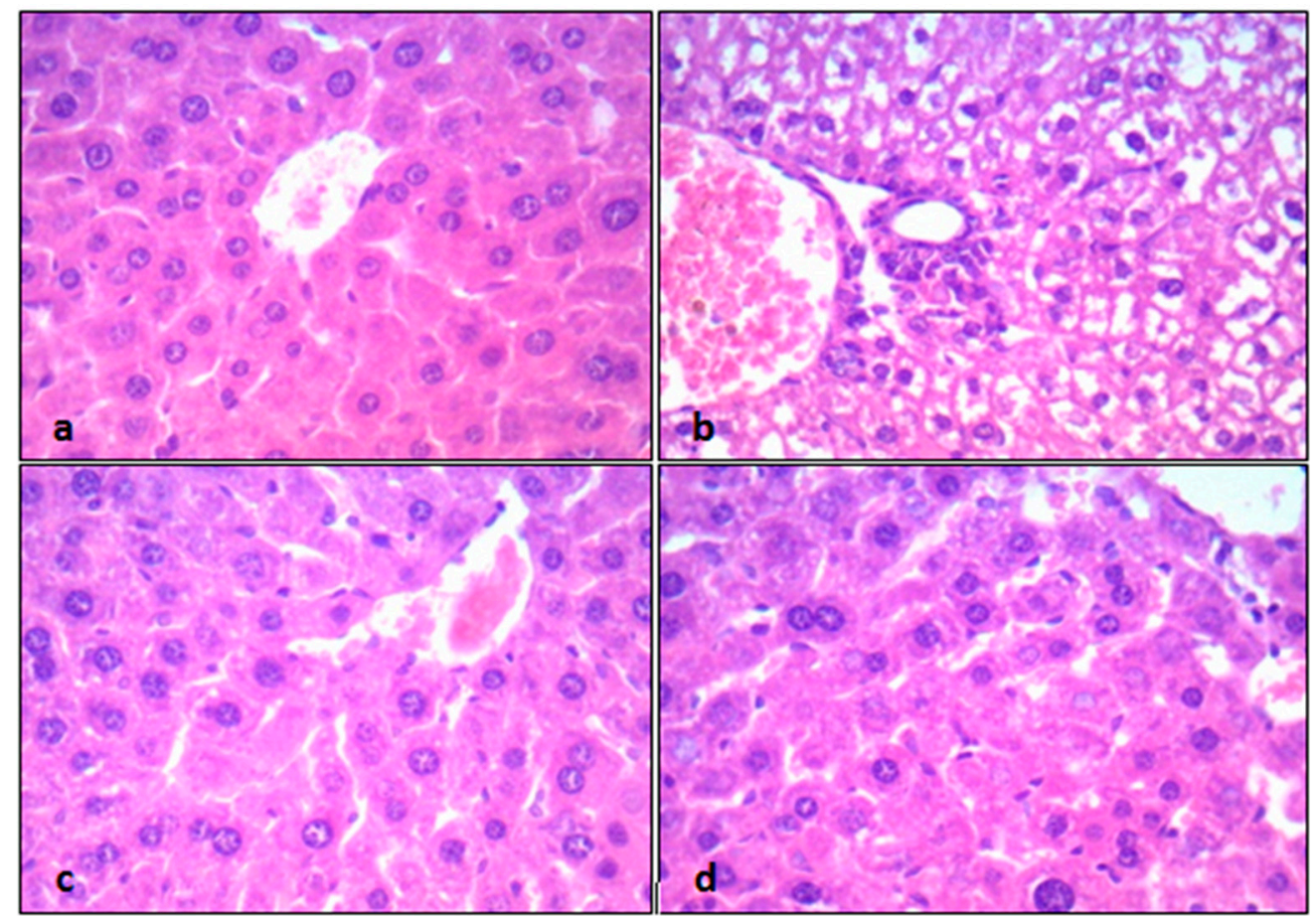

Figure 3. The protective effect of different doses of EPO on hepatic histopathology, induced by cyclophosphamide: (a) Control mice, (b) CP-intoxicated mice, (c) CP + EPO $5 \mathrm{mg} / \mathrm{kg} /$ day mice, and (d) $\mathrm{CP}+\mathrm{EPO} 10 \mathrm{mg} / \mathrm{kg} /$ day mice. All sections captured at 400× magnification, using objective 40×, UIS optical system (Universal Infinity System, Olympus ${ }^{\circledR}$, Tokyo, Japan).

Similarly, pancreatic tissue sections from control mice showed normal pancreatic acini with basal nuclei and amphophilic cytoplasm. The cells of the islets of Langerhans showed abundant eosinophilic cytoplasm and central small nuclei, and were arranged in trabecular and acinar patterns (Figure 4a). However, the pancreatic acini in CP-intoxicated mice showed focal moderate hydropic degeneration and moderate edema and congestion. In addition, the islets of Langerhans were markedly irregular and reduced in size with atrophic and shrunken cells (Figure $4 \mathrm{~b}$ ). On the other hand, group III mice $(\mathrm{CP}+\mathrm{EPO} 5 \mathrm{mg} / \mathrm{kg} /$ day) showed some improvement with a residual decrease in the size of islets of Langerhans, mild degeneration of pancreatic acini, and moderate congestion (Figure 4c). Group IV (CP + EPO $10 \mathrm{mg} / \mathrm{kg} /$ day) mice showed marked improvements with normal pancreatic acini and regular, normal-sized islets of Langerhans with abundant eosinophilic cytoplasm and central small nuclei (Figure 4d). Histopathological scoring confirmed the significant protective effects of primrose oil against CP-induced hepatic and pancreatic damages (Table 4).

Table 4. The histopathological scoring system for (a) hepatic and (b) pancreatic tissues in CP-intoxicated mice treated with different doses of evening primrose oil.

\begin{tabular}{cccccc}
\hline \multirow{2}{*}{ Groups } & \multicolumn{4}{c}{ Grades } & \multirow{2}{*}{$\begin{array}{c}\text { Mean Scoring Grades for Hepatic } \\
\text { Histopathological Changes }\end{array}$} \\
\cline { 2 - 5 } & $\mathbf{1}$ & $\mathbf{2}$ & $\mathbf{3}$ & $\mathbf{4}$ & $1.125 \pm 0.13$ \\
\hline Control & 7 & 1 & 0 & 0 & $3.25 \pm 0.25^{\mathrm{a}}$ \\
\hline CP-intoxicated & 0 & 1 & 4 & 3 & $2.37 \pm 0.26^{\mathrm{ab}}$ \\
\hline CP + EPO $(\mathbf{5 ~} \mathbf{~ m g} / \mathbf{k g})$ & 0 & 6 & 1 & 1 & $1.63 \pm 0.42^{\mathrm{b}}$ \\
\hline CP + EPO $(\mathbf{1 0} \mathbf{~ m g / k g )}$ & 6 & 1 & 1 & 0 & (a)
\end{tabular}


Table 4. Cont.

\begin{tabular}{|c|c|c|c|c|c|}
\hline \multirow{2}{*}{ Groups } & \multicolumn{4}{|c|}{ Grades } & \multirow{2}{*}{$\begin{array}{l}\text { Mean Scoring Grades for Pancreatic } \\
\text { Histopathological Changes }\end{array}$} \\
\hline & 1 & 2 & 3 & 4 & \\
\hline Control & 6 & 1 & 1 & 0 & $1.37 \pm 0.26$ \\
\hline CP-intoxicated & 0 & 1 & 4 & 3 & $3.37 \pm 0.18^{a}$ \\
\hline $\mathrm{CP}+\mathrm{EPO}(5 \mathrm{mg} / \mathrm{kg})$ & 0 & 6 & 1 & 1 & $2.5 \pm 0.26^{\mathrm{ab}}$ \\
\hline CP + EPO (10 mg/kg) & 6 & 1 & 1 & 0 & $1.5 \pm 0.26^{b c}$ \\
\hline
\end{tabular}

(b)

CP: cyclophosphamide, EPO: evening primrose oil. All data are expressed as mean \pm SEM and analyzed using the one-way ANOVA, followed by Bonferroni's post-hoc test at $p<0.05$. a Significantly different from the control mice, b Significantly different from CP-intoxicated mice, ${ }^{c}$ Significantly different from CP + EPO (5 mg/kg) mice.

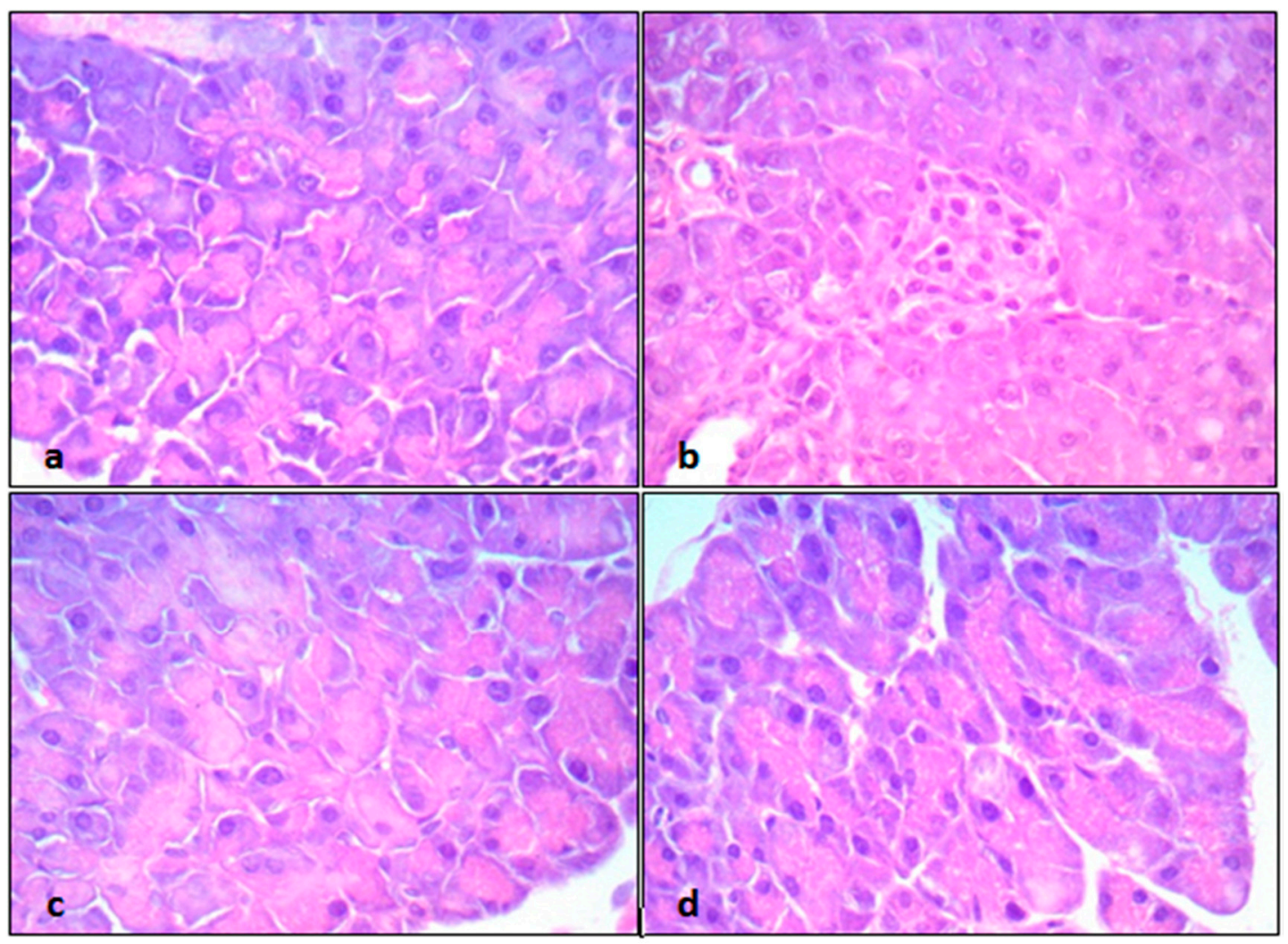

Figure 4. The protective effect of different doses of EPO on pancreatic histopathology, induced by cyclophosphamide: (a) Control mice, (b) CP-intoxicated mice, (c) CP + EPO $5 \mathrm{mg} / \mathrm{kg} /$ day mice, and (d) $\mathrm{CP}+\mathrm{EPO} 10 \mathrm{mg} / \mathrm{kg} /$ day mice. All sections captured at 400× magnification, using objective 40×, UIS optical system (Universal Infinity System, Olympus ${ }^{\circledR}$, Tokyo, Japan).

\subsection{DNA Laddering}

DNA laddering assay (Figure 5) showed that in both hepatic (A) and pancreatic (B) tissues, CP administration (lane 2) caused remarkable fragmentation of genomic DNA compared to control mice (lane 1). In the group treated with EPO (5 mg/kg/day) prior to CP administration, DNA fragmentation was slightly decreased (lane 3). However, there was a marked reduction of DNA damage in the group treated with EPO at $10 \mathrm{mg} / \mathrm{kg} /$ day (lane 4), especially in the pancreatic tissue. 


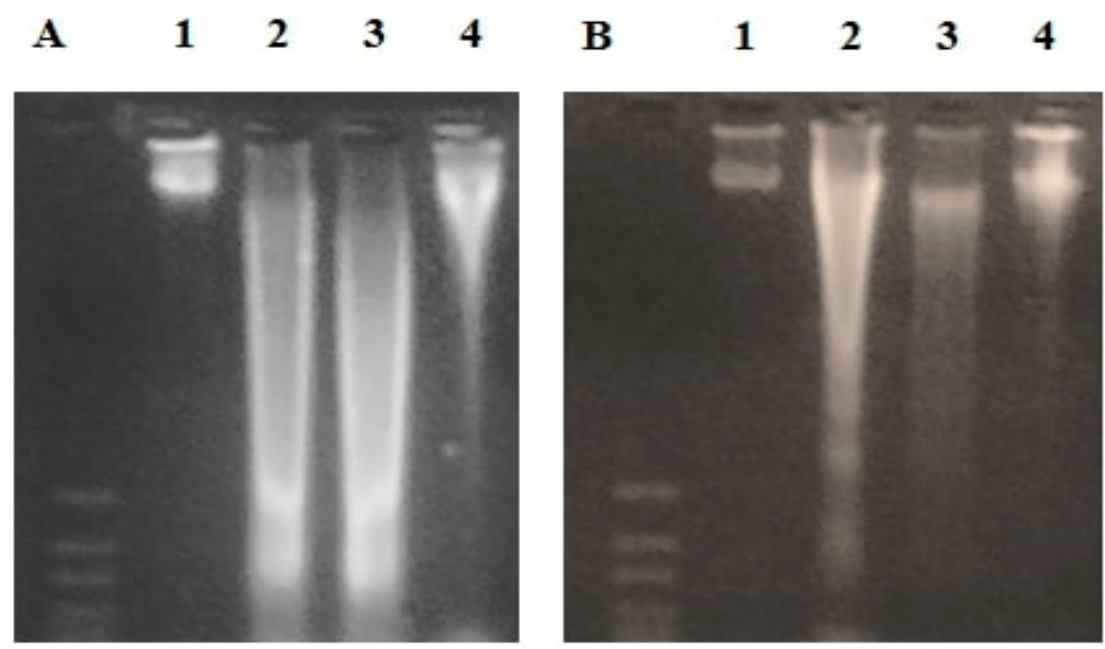

Figure 5. Horizontal gel electrophoresis of genomic DNA extracted from (A) liver, and (B) pancreas of experimental mice. Lane (1): Control mice. Lane (2): CP-intoxicated mice. Lane (3): CP + EPO (5 mg/kg/day). Lane (4): CP + EPO (10 mg/kg/day).

\section{Discussion}

In the current study, acute intoxication with CP caused significant injuries to mice hepatic and pancreatic tissues as revealed by biochemical, histopathological, and genotoxicity analyses. Cyclophosphamide is an anti-neoplastic agent, incorporated in several anti-cancer regimens. There is evidence in the literature for CP-induced hepatotoxicity $[15,16]$ and some reports of CP-related pancreatic dysfunction and diabetic changes $[17,18]$. The suggested mechanisms for $\mathrm{CP}$-induced liver toxicity include exposure to the CP metabolite (o-carboxyethyl-phosphoramide mustard), which is related to biliary obstruction [15], oxidative stress (related to another metabolite: acrolein) [5], and lymphocytic infiltration [19]. The CP-induced pancreatic toxicity may be an idiosyncratic reaction or secondary to hepatotoxicity [18].

Cyclophosphamide acts partly through increasing the production of ROS in malignant cells; however, it also induces oxidative stress in different body tissues [5]. In our study, subcutaneous (S.C) injection with two subsequent doses of $\mathrm{CP}$ was associated with significant increases in hepatic and pancreatic MDA concentrations. Similar findings were reported in earlier investigations [20,21]. This reflects increased lipid peroxidation in CP-intoxicated mice. The CP-induced oxidative stress may also explain the observed genotoxicity, manifested as increased levels of DNA fragmentation in our DNA laddering experiment.

In addition, intoxication with $\mathrm{CP}$ was associated with significant increases in both hepatic and pancreatic tissue concentrations of TNF- $\alpha$. Ohtani et al. [22] showed that 4-hydroxycyclophosphamide (4-HC), a metabolite of CP enhances TNF- $\alpha$ mediated DNA fragmentation (which was also observed in the current study). Further, TNF- $\alpha$ was shown to play a role in CP-induced apoptosis in vascular endothelial cells [22] and hemorrhagic cystitis [23]. Our findings uncover the involvement of TNF- $\alpha$ in $\mathrm{CP}$-induced toxicity in other body tissues (liver and pancreas).

Histopathological examination of liver tissue sections in CP-intoxicated mice showed disturbed tissue architecture, hydropic degeneration, congested central veins, and inflammatory infiltrates. Similar findings were noticed in CP-intoxicated mice after a single intraperitoneal dose of $200 \mathrm{mg} / \mathrm{kg}$ of CP [19]. In the pancreatic tissue, CP treatment was associated with atrophic islets of Langerhans with hydropic degeneration and moderate edema. In the same vein, former studies showed that $\mathrm{CP}$ can induce accelerated diabetes in mice via caspase-3 overexpression and B-cell apoptosis [24,25].

Interestingly, pretreatment with EPO (at two doses: 5 and $10 \mathrm{mg} / \mathrm{kg} /$ day for 14 days) before $\mathrm{CP}$ intoxication ameliorated all investigated CP-induced oxidative, inflammatory, histopathological, and genotoxic changes. Previous studies have highlighted the antioxidant potential of EPO in vitro [26] and 
in vivo in animal models with subacute aflatoxin toxicity [27] and hyperlipidemia [12]. Further, EPO treatment reduced the DNA fragmentation, induced by CP. Similarly, a former study showed that EPO can ameliorate the genotoxicity of ifosfamide [28]. These effects may be mediated by the established antioxidant effects of EPO, which were further confirmed in this study by the significant reduction of tissue MDA in EPO-treated mice. Of note, $\mathrm{CP}$ systemic toxicity is related to hepatic $\mathrm{CP}$ metabolism that produces toxic metabolites. Therefore, EPO may ameliorate $\mathrm{CP}$ toxicity by reducing the generation of $\mathrm{CP}$ toxic metabolites in the liver. However, this mechanism needs further confirmation.

In addition, EPO showed marked anti-inflammatory effects in our study as manifested by the significant reduction of tissue TNF- $\alpha$ levels and amelioration of inflammatory infiltrates on histopathological examination in mice, pretreated with EPO. The anti-inflammatory effects of EPO were previously reported in vitro [26], and in clinical studies in diabetes [10], rheumatoid arthritis [29], and atopic dermatitis [30]. One suggested mechanism was that EPO is rich in dihomo- $\gamma$-linolenic acid that stops the transformation of arachidonic acid into leukotrienes [29]. The observed effects of EPO on TNF- $\alpha$ in our study confirm the findings of prior studies in the literature [31,32].

Another interesting finding in our study was the increased insulin secretion in EPO-treated mice and restoration of normal insulin levels in the $10 \mathrm{mg} / \mathrm{kg}$ bw EPO group. Published data shows that EPO can increase insulin secretion [33], ameliorate metabolic abnormalities in diabetic patients [12] and reduce the risk of vascular complications $[10,34]$. Improved insulin secretion may be attributed to the reduction of oxidative stress, inflammation, and subsequent destruction of $\beta$-cells (as demonstrated in our histopathological examination).

To identify the active constituents in our sample that may be responsible for the observed protective effects, we performed GC-MS analysis. The major component in our sample was $3 \beta$-Sitosterol. This compound has been shown to possess antioxidant, anti-inflammatory, and antidiabetic effects $[35,36]$ and may be responsible in part for the observed effects for evening primrose oil. Similar effects were reported for $\beta$-Caryophyllene [37]. Another major component was Campesterol, which -along with $3 \beta$-Sitosterol were shown before to modulate the release of pro-inflammatory cytokines [32]. However, other less abundant molecules may be responsible for these effects as abundance does not equal efficacy; thus, future studies should determine the exact molecules to which the observed benefits of EPO can be attributed. Further, to confirm that EPO does not antagonize the anti-tumor activity of $\mathrm{CP}$, further comparative studies in tumor-bearing mice are planned. Therefore, more data are needed before translating the findings of the current study into human research.

\section{Materials and Methods}

\subsection{Ethics Statement}

All used experimental procedures were approved by the Research Ethics Committee at the Faculty of Pharmacy, Suez Canal University, Ismailia, Egypt (Approval No. 201512A9).

\subsection{Experimental Animals}

Male Swiss albino mice (weighing 28-35 g) were supplied by the Egyptian Organization for Biological Products and Vaccines (Cairo, Egypt). Mice were housed in groups of eight in polyethylene cages with normal dark/light cycle and temperature between $25 \pm 3^{\circ} \mathrm{C}$. Mice could acclimatize for 7 days before initiating the experiment and were freely provided with water and food ad libitum.

Cyclophosphamide monohydrate (CAS No: 6055-19-2) was obtained from Sigma-Aldrich (St. Louis, $\mathrm{MO}, \mathrm{USA})$, then prepared by dissolving in water $\left(5 \mathrm{~g} / 100 \mathrm{~mL}\right.$ at $\left.23^{\circ} \mathrm{C}\right)$ taking in consideration that the aqueous solution of cyclophosphamide is light-sensitive. Evening primrose oil (Primrose Plus ${ }^{\circledR}$ capsules) was purchased from EMA-Pharmaceuticals (Moncay, Lailly-en-Val, France).

To assess EPO chemical composition, we used Trace GC Ultra-ISQ mass spectrometer (Thermo Scientific, Austin, TX, USA). For a start, we held the column oven temperature at $60{ }^{\circ} \mathrm{C}$ and then increased it to $220^{\circ} \mathrm{C}$ (held for $2 \mathrm{~min}$ ), and then to $300{ }^{\circ} \mathrm{C}$ (at a rate of $5^{\circ} \mathrm{C} / \mathrm{min}$ ). The MS transfer line 
and injector temperatures were kept at $270{ }^{\circ} \mathrm{C}$. Using Autosampler AS3000 along with GC (split mode), we injected diluted samples of $1 \mu \mathrm{L}$ (with a solvent delay of $3 \mathrm{~min}$ ). We collected EI mass spectra at $70 \mathrm{eV}$ ionization voltages over the range of $m / z$ 40-650 in full-scan mode. The transfer line and ion source were set at $280^{\circ} \mathrm{C}$ and $200{ }^{\circ} \mathrm{C}$, respectively. The sample components were identified by comparing their mass spectra and retention times with those of the WILEY 09/NIST 11 database.

\subsection{Experimental Design}

Mice were randomly divided into four equal groups. Group I mice were treated with saline (control mice); group II mice were treated with two S.C doses of CP $(100 \mathrm{mg} / \mathrm{kg} / \mathrm{day}$ on the 15 th and 16th days of the experiment $=200 \mathrm{mg} / \mathrm{kg}$ total) [2]; while group III and group VI mice were treated with 5 and $10 \mathrm{mg} / \mathrm{kg} /$ day bw EPO respectively for 14 days [28] followed by two S.C doses of CP $(100 \mathrm{mg} / \mathrm{kg} /$ day) on the $15 \mathrm{th}$ and 16 th day of the experiment.

\subsection{Sample Collection and Preparation}

Mice were sacrificed under isoflurane anesthesia. The liver and pancreas of each mouse were rapidly dissected and washed with ice cold $\mathrm{NaCl} 0.9 \%$ solution. Parts of the liver $(0.3 \mathrm{~g})$ and pancreas $(0.1 \mathrm{~g})$ were blotted and kept at $-80^{\circ} \mathrm{C}$. These tissues were homogenized in phosphate buffer $(\mathrm{pH} 7.4)$ for biochemical assays, and then centrifuged at $3000 \times g$ and $4{ }^{\circ} \mathrm{C}$ for $15 \mathrm{~min}$.

\subsection{Measurement of Biochemical Parameters}

\subsubsection{Determination of Serum Level of Liver Enzymes and Pancreatic Amylase}

Blood samples were withdrawn from each rat from the orbital sinus to obtain the sera which were used to determine the concentrations of SGPT and SGOT using commercial kits (Biocon Diagnostic, Vöhl, Germany) and a UV-visible spectrophotometer (UV-1601PC, Shimadzu, Japan). The serum $\alpha$-amylase activity was determined by an enzymatic colorimetric test using 2-choloro-4-nitrofenylo- $\alpha$-maltrioside (CNPG3) [38].

\subsubsection{Determination of Fasting Serum Insulin Level}

Fasting serum insulin was estimated using an enzyme-linked immunosorbent assay (ELISA) kit for insulin (Biorbyt, UK) following the manufacturer's protocols (Crystal Chem Inc., Downers Grove, IL, USA).

\subsubsection{Measurement of Tissue Homogenate Level of TNF- $\alpha$ and MDA}

The tissue concentrations of TNF- $\alpha$ were determined, using a commercially available ELISA Kit (Biosource ${ }^{\circledR}$, Camarillo, CA, USA) following the instructions of the manufacturer. TNF- $\alpha$ was expressed as $\mathrm{pg} / \mathrm{g}$ tissue. The tissue MDA concentration was measured following the methods of Mihara and Uchiyama [39].

\subsection{Histopathological Examination}

Additionally, liver and pancreas tissue samples were cut $5 \mathrm{~mm}$ apart from the edge of the largest hepatic lobe and the remaining part of the pancreas, respectively, and then fixed with $10 \%$ $(v / v)$ formaldehyde and paraffin wax, and stained with hematoxylin and eosin (H\&E) stain for histopathological examinations. An experienced pathologist who was masked to the animal groups conducted the histological examinations. A semiquantitative method, proposed by Dixon et al. [40], was used to assess the observed pathological changes. 


\subsection{DNA Laddering}

Genomic DNA was extracted and purified form homogenized liver and pancreas tissues using Wizard ${ }^{\circledR}$ Genomic DNA Purification kit (Promega, Madison, WI, USA). Extracted DNA was tested for concentration and purity by Nanodrop ${ }^{\circledR}$ NA-1000 UV/Vis (ThermoFisher spectrophotometer, Wilmington, DE, USA). DNA fragmentation was assessed by horizontal electrophoresis using $2 \%$ agarose gel stained with ethidium bromide. A total of $10 \mu \mathrm{L}$ of each DNA sample was mixed with $2 \mu \mathrm{L}$ of the loading dye (ThermoFischer Scientific Inc, Waltham, MA, USA). Mixed samples were loaded to the prepared agarose gel. Electric current (90 volt) was applied for $45 \mathrm{~min}$ followed by visualization using UV trans-illuminator.

\subsection{Statistical Analysis}

Results were expressed as mean \pm standard error of mean (SEM) and analyzed using the SPSS program version 16 (Chicago, IL, USA). Numerical data were compared using the one-way analysis of variance, supplemented by Bonferroni's multiple comparisons test. Differences were considered significant at $p \leq 0.05$.

\section{Conclusions}

Pretreatment with EPO-in a dose-dependent manner-showed significant antioxidant, anti-inflammatory, and genoprotective effects against the toxic effects of $\mathrm{CP}$. This resulted in marked alleviation of hepatic and pancreatic tissue injuries in CP-intoxicated mice.

Author Contributions: Conceptualization, D.M.K. and E.T.M.; methodology, D.M.K., E.T.M., and A.I.A.; software, A.I.A.; validation, D.M.K. and E.T.M.; formal analysis, A.I.A.; investigation, M.M.A.-D.; resources, D.M.K.; data curation, A.I.A.; writing - review and editing, A.I.A.; supervision, M.M.A.-D.; funding acquisition, M.M.A.-D. All authors have read and agreed to the published version of the manuscript.

Funding: This work was funded by Researchers Supporting Project number (RSP 2019/ 121), King Saud University, Riyadh, Saudi Arabia.

Acknowledgments: This work was funded by Researchers Supporting Project number (RSP 2019/ 121), King Saud University, Riyadh, Saudi Arabia.

Conflicts of Interest: The authors declare no conflict of interest.

\section{References}

1. Ahlmann, M.; Hempel, G. The effect of cyclophosphamide on the immune system: Implications for clinical cancer therapy. Cancer Chemother. Pharmacol. 2016, 78, 661-671. [CrossRef]

2. Habibi, E.; Shokrzadeh, M.; Chabra, A.; Naghshvar, F.; Keshavarz-Maleki, R.; Ahmadi, A. Protective effects of Origanum vulgare ethanol extract against cyclophosphamide-induced liver toxicity in mice. Pharm. Biol. 2015, 53, 10-15. [CrossRef]

3. Emadi, A.; Jones, R.J.; Brodsky, R.A. Cyclophosphamide and cancer: Golden anniversary. Nat. Rev. Clin. Oncol. 2009, 6, 638. [CrossRef]

4. Zhang, J.; Tian, Q.; Yung Chan, S.; Chuen Li, S.; Zhou, S.; Duan, W.; Zhu, Y.-Z. Metabolism and transport of oxazaphosphorines and the clinical implications. Drug Metab. Rev. 2005, 37, 611-703. [CrossRef] [PubMed]

5. Jeelani, R.; Khan, S.N.; Shaeib, F.; Kohan-Ghadr, H.-R.; Aldhaheri, S.R.; Najafi, T.; Thakur, M.; Morris, R.; Abu-Soud, H.M. Cyclophosphamide and acrolein induced oxidative stress leading to deterioration of metaphase II mouse oocyte quality. Free Radic. Biol. Med. 2017, 110, 11-18. [CrossRef] [PubMed]

6. Amiri, F.T.; Hamzeh, M.; Beklar, S.Y.; Hosseinimehr, S.J. Anti-apoptotic and antioxidant effect of cerium oxide nanoparticles on cyclophosphamide-induced hepatotoxicity. Erciyes Med. J. 2018, 40, 148-154. [CrossRef]

7. Hamzeh, M.; Hosseinimehr, S.J.; Khalatbary, A.R.; Mohammadi, H.R.; Dashti, A.; Amiri, F.T. Atorvastatin mitigates cyclophosphamide-induced hepatotoxicity via suppression of oxidative stress and apoptosis in rat model. Res. Pharm. Sci. 2018, 13, 440. 
8. Munir, R.; Semmar, N.; Farman, M.; Ahmad, N.S. An updated review on pharmacological activities and phytochemical constituents of evening primrose (genus Oenothera). Asian Pac. J. Trop. Biomed. 2017, 7, 1046-1054. [CrossRef]

9. Edwards, S.; Rocha, I.C.; Williamson, E.M.; Heinrich, M. Evening Primrose (Oil). In Phytopharmacy: An Evidence-Based Guide to Herbal Medical Products; John Wiley \& Sons, Ltd.: Hoboken, NJ, USA, 2015; pp. 144-148.

10. SafaaHussain, M.; Abdulridha, M.K.; Khudhair, M.S. Anti-inflammatory, Anti-oxidant, and Vasodilating Effect of Evening Primrose Oil in Type 2 Diabetic Patients. Int. J. Pharm. Sci. Rev. Res 2016, 39, 173-178.

11. Granica, S.; Czerwińska, M.E.; Piwowarski, J.P.; Ziaja, M.; Kiss, A.K. Chemical composition, antioxidative and anti-inflammatory activity of extracts prepared from aerial parts of Oenothera biennis L. and Oenothera paradoxa Hudziok obtained after seeds cultivation. J. Agric. Food Chem. 2013, 61, 801-810. [CrossRef]

12. Jamilian, M.; Karamali, M.; Taghizadeh, M.; Sharifi, N.; Jafari, Z.; Memarzadeh, M.R.; Mahlouji, M.; Asemi, Z. Vitamin D and evening primrose oil administration improve glycemia and lipid profiles in women with gestational diabetes. Lipids 2016, 51, 349-356. [CrossRef] [PubMed]

13. Borchardt, J.R.; Wyse, D.L.; Sheaffer, C.C.; Kauppi, K.L.; Fulcher, R.G.; Ehlke, N.J.; Biesboer, D.D.; Bey, R.F. Antioxidant and antimicrobial activity of seed from plants of the Mississippi river basin. J. Med. Plants Res. 2008, 2, 081-093.

14. Rock, E.; DeMichele, A. Nutritional approaches to late toxicities of adjuvant chemotherapy in breast cancer survivors. J. Nutr. 2003, 133, 3785S-3793S. [CrossRef] [PubMed]

15. McDonald, G.B.; Slattery, J.T.; Bouvier, M.E.; Ren, S.; Batchelder, A.L.; Kalhorn, T.F.; Schoch, H.G.; Anasetti, C.; Gooley, T. Cyclophosphamide metabolism, liver toxicity, and mortality following hematopoietic stem cell transplantation. Blood 2003, 101, 2043-2048. [CrossRef] [PubMed]

16. Subramaniam, S.R.; Cader, R.A.; Mohd, R.; Yen, K.W.; Ghafor, H.A. Low-dose cyclophosphamide-induced acute hepatotoxicity. Am. J. Case Rep. 2013, 14, 345.

17. Sharma, P.K.; Misra, A.K.; Singh, V.; Gupta, A.; Saroha, S.; Singh, S. Cyclophosphamide and epirubicin-induced diabetes mellitus in breast cancer: A rare occurrence. J. Pharmacol. Pharmacother. 2016, 7, 146.

18. Salvador, V.B.; Singh, M.; Witek, P.; Peress, G. Cyclophosphamide and Doxorubicin-induced acute pancreatitis in a patient with breast cancer. Br. J. Med Pract. 2014, 7, 727.

19. Shokrzadeh, M.; Ahmadi, A.; Naghshvar, F.; Chabra, A.; Jafarinejhad, M. Prophylactic efficacy of melatonin on cyclophosphamide-induced liver toxicity in mice. Biomed Res. Int. 2014, 2014, 470425. [CrossRef]

20. Nafees, S.; Rashid, S.; Ali, N.; Hasan, S.K.; Sultana, S. Rutin ameliorates cyclophosphamide induced oxidative stress and inflammation in Wistar rats: Role of NFKB/MAPK pathway. Chem. Biol. Interact. 2015, 231, 98-107. [CrossRef]

21. Mahmoud, A.M.; Germoush, M.O.; Alotaibi, M.F.; Hussein, O.E. Possible involvement of Nrf2 and PPAR $\gamma$ up-regulation in the protective effect of umbelliferone against cyclophosphamide-induced hepatotoxicity. Biomed. Pharmacother. 2017, 86, 297-306. [CrossRef]

22. Ohtani, T.; Nakamura, T.; Toda, K.; Furukawa, F. Cyclophosphamide enhances TNF-alpha-induced apoptotic cell death in murine vascular endothelial cell. FEBS Lett. 2006, 580, 1597-1600. [CrossRef] [PubMed]

23. Kim, S.H.; Lee, I.C.; Ko, J.W.; Moon, C.; Kim, S.H.; Shin, I.S.; Seo, Y.W.; Kim, H.C.; Kim, J.C. Diallyl disulfide prevents cyclophosphamide-induced hemorrhagic cystitis in rats through the inhibition of oxidative damage, MAPKs, and NF-kB pathways. Biomol. Ther. 2015, 23, 180. [CrossRef] [PubMed]

24. O’Brien, B.A.; Harmon, B.V.; Cameron, D.P.; Allan, D.J. Nicotinamide prevents the development of diabetes in the cyclophosphamide-induced NOD mouse model by reducing beta-cell apoptosis. J. Pathol. 2000, 191, 86-92. [CrossRef]

25. Reddy, S.; Bradley, J.; Ginn, S.; Pathipati, P.; Ross, J.M. Immunohistochemical study of caspase-3-expressing cells within the pancreas of non-obese diabetic mice during cyclophosphamide-accelerated diabetes. Histochem. Cell Biol. 2003, 119, 451-461. [CrossRef]

26. Knorr, R.; Hamburger, M. Quantitative analysis of anti-inflammatory and radical scavenging triterpenoid esters in evening primrose oil. J. Agric. Food Chem. 2004, 52, 3319-3324. [CrossRef]

27. Kanbur, M.; Eraslan, G.; Sarıca, Z.S.; Aslan, Ö. The effects of evening primrose oil on lipid peroxidation induced by subacute aflatoxin exposure in mice. Food Chem. Toxicol. 2011, 49, 1960-1964. [CrossRef]

28. Mohamed, H. Prophyloctic Effect of the Evening Primrose Oil on Genotoxicity of the Anticancer Drug Ifosfamide in Mice. Egypt. J. Zool. 2012, 174, 1-32. 
29. Soeken, K.; Miller, S.; Ernst, E. Herbal medicines for the treatment of rheumatoid arthritis: A systematic review. Rheumatology 2003, 42, 652-659. [CrossRef]

30. Chung, B.Y.; Park, S.Y.; Jung, M.J.; Kim, H.O.; Park, C.W. Effect of evening primrose oil on Korean patients with mild atopic dermatitis: A randomized, double-blinded, placebo-controlled clinical study. Ann. Dermatol. 2018, 30, 409-416. [CrossRef]

31. Montserrat-de la Paz, S.; Garcia-Gimenez, M.D.; Angel-Martin, M.; Perez-Camino, M.C.; Fernandez Arche, A. Long-chain fatty alcohols from evening primrose oil inhibit the inflammatory response in murine peritoneal macrophages. J. Ethnopharmacol. 2014, 151, 131-136. [CrossRef]

32. Montserrat-de la Paz, S.; Fernandez-Arche, A.; Angel-Martin, M.; Garcia-Gimenez, M.D. The sterols isolated from Evening Primrose oil modulate the release of proinflammatory mediators. Phytomedicine 2012, 19, 1072-1076. [CrossRef] [PubMed]

33. Abdulridha, M.; Hussain, M.; Khudhair, M. Study Effect of Evening Primrose Oil Supplement on Type 2 Diabetes Mellitus-Associated Metabolic Parameters. UK J. Pharm. Biosci. 2017, 5, 17-23. [CrossRef]

34. Jack, A.M.; Keegan, A.; Cotter, M.A.; Cameron, N.E. Effects of diabetes and evening primrose oil treatment on responses of aorta, corpus cavernosum and mesenteric vasculature in rats. Life Sci. 2002, 71, 1863-1877. [CrossRef]

35. Sujatha, S.; Anand, S.; Sangeetha, K.; Shilpa, K.; Lakshmi, J.; Balakrishnan, A.; Lakshmi, B. Biological evaluation of (3ß)-STIGMAST-5-EN-3-OL as potent anti-diabetic agent in regulating glucose transport using in vitro model. Int. J. Diabetes Mellit. 2010, 2, 101-109. [CrossRef]

36. Patra, A.; Jha, S.; Murthy, P.; Manik, S.A. Isolation and characterization of stigmast-5-en-3 $\beta$-ol ( $\beta$-sitosterol) from the leaves of Hygrophila spinosa T. Anders. Int. J. Pharma Sci. Res. 2010, 1, 95-100.

37. Basha, R.H.; Sankaranarayanan, C. $\beta$-Caryophyllene, a natural sesquiterpene lactone attenuates hyperglycemia mediated oxidative and inflammatory stress in experimental diabetic rats. Chem. Biol. Interact. 2016, 245, 50-58. [CrossRef]

38. Kurahashi, M.; Inomata, K. Amylase secretion by parotid glands and pancreas of diabetic rats during feeding. Am. J. Physiol. Gastrointest. Liver Physiol. 1988, 254, G878-G882. [CrossRef]

39. Mihara, M.; Uchiyama, M. Determination of malonaldehyde precursor in tissues by thiobarbituric acid test. Anal. Biochem. 1978, 86, 271-278.

40. Dixon, J.B.; Bhathal, P.S.; Hughes, N.R.; O’Brien, P.E. Nonalcoholic fatty liver disease: Improvement in liver histological analysis with weight loss. Hepatology 2004, 39, 1647-1654. [CrossRef]

Sample Availability: Samples of the compounds cyclophosphamide and evening primrose oil are available from the authors.

(C) 2020 by the authors. Licensee MDPI, Basel, Switzerland. This article is an open access article distributed under the terms and conditions of the Creative Commons Attribution (CC BY) license (http://creativecommons.org/licenses/by/4.0/). 